\title{
The Cytotoxic Effect of Eurycoma longifolia Jack Root Extract on The Prostate Adenocarcinoma PC-3 Cells through Apoptosis Enhancement
}

\author{
Eka Yudha Rahman ${ }^{1,2 \star}$, Kusworini Kusworini ${ }^{3}$, Mulyohadi $\mathrm{Ali}^{4}$, Basuki Bambang Purnomo ${ }^{5}$, Nia Kania ${ }^{6}$ \\ ${ }^{1}$ Doctoral Program of Medical Science, Faculty of Medicine, University of Brawijaya Malang, Indonesia; ${ }^{2}$ Departemen of Surgery, \\ Urology Division, Faculty of Medicine, University of Lambung Mangkurat Banjarmasin, Indonesia; ${ }^{3}$ Departement of Clinical \\ Pathology, Faculty of Medicine, University of Brawijaya Malang, Indonesia; ${ }^{4}$ Departement of Pharmacology, Faculty of \\ Medicine, University of Brawijaya Malang, Indonesia; ${ }^{5}$ Departement of Urology, Faculty of Medicine, University of Brawijaya \\ Malang, Indonesia; ${ }^{6}$ Departemen of Anatomical Pathology, Faculty of Medicine, University of Lambung Mangkurat Banjarmasin, \\ Indonesia
}

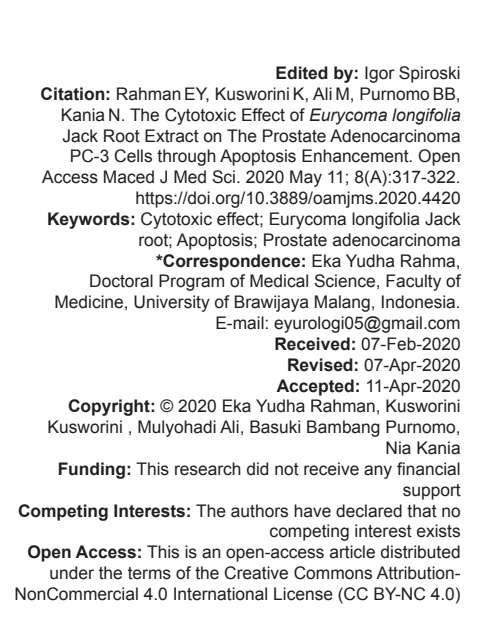

\section{Abstract}

BACKGROUND: Prostate cancer is the second most common malignancy in men and has become the sixth leading cause of death in males worldwide. Eurycoma longifolia Jack root has active compounds, namely, quassinoids eurycomanone, and canthine, which have potential as detoxicants, free radical antioxidants, and anticancer.

AIM: This study aimed to analyze the potential of the active compounds in E. longifolia Jack root in induce apoptosis in the prostate adenocarcinoma PC-3 cells.

METHODS: E. Iongifolia root active compounds were obtained by extracting them using ethanol solvent. The culture of prostate cancer PC-3 cell line was obtained from androgen-independent prostate adenocarcinoma with bone metastasis use as subject. Examination of the potency of E. longifolia root extract was conducted by observing the cells undergoing apoptosis with TUNEL assay.

RESULTS: One-way ANOVA test showed that the increase in apoptotic cells was associated proportionally with the concentration levels of $E$. longifolia root extract and showed a significant difference $(\alpha<0.05)$

CONCLUSION: The higher the dose of E. longifolia root extract, the higher will be the apoptotic level of adenocarcinoma cells PC3. E. longifolia extract is potentially used in the treatment of prostate cancer by inducing apoptotic mechanisms.

\section{Background}

Prostate cancer is the second most frequent cancer diagnosis made in men and the fifth leading cause of death worldwide. Prostate cancer may be asymptomatic at the early stage and often has an indolent course that may require only active surveillance. Based on GLOBOCAN 2018 estimates, 1,276,106 new cases of prostate cancer were reported worldwide and causing 358,989 deaths $(3.8 \%$ of all deaths caused by cancer in men) in 2018, with higher prevalence in the developed countries [1], [2]. Based on the 2011 Indonesian Society of Urologic Oncology (ISUO) data during 2006-2010, there were 971 prostate cancer patients. The average age was 68.3 years old, most were between 70 and 79 years $(37.6 \%)$. The most common stage was Stage 4 (490 patients, $50.5 \%$ ) [3].

Eurycoma longifolia Jack is a tropical plant from Simaroubaceae family distributed in Southeast
Asia [4]. The root of E. longifolia Jack has several active compounds. E. longifolia Jack has been used as detoxicants, free radical antioxidants, and anticancer [5], [6]. Compounds in E. Iongifolia Jack are quassinoids [7], [8], [9]), alkaloid 9-methoxycanthine-6-one [10], [11], and alkaloid canthinone [12]. Quassinoids have cytostatic effect on colon cancer, breast cancer, pulmonary cancer, skin cancer (melanoma), and fibrosarcoma [13].

The objective of this study was to analyze the potency of active compounds of E. longifolia Jack root in induced apoptosis in prostate adenocarcinoma PC-3 cells by TUNEL assay.

\section{Methods}

This study was experimental in vitro with posttest control group design. The subject of this study is 
prostate cancer PC-3 cell line which was obtained from androgen-independent prostate adenocarcinoma with bone metastasis.

\section{Species identification of E. Iongifolia Jack}

E. Iongifolia Jack roots were obtained from Great Jungle Park of Sultan Adam, Mandiangin Village, Banjar Regency, South Kalimantan. Morphological identification to determine $E$. longifolia Jack species was conducted in the UPT Plant Conservation Center, LIPI, Purwodadi.

\section{E. longifolia Jack root extract}

E. longifolia Jack roots were sliced thinly and then dried indirectly under the sun or aerated completely if there is no difference in weight during weighing. After they were dried, E. longifolia Jack roots were pulverized with blender and then weighed with analytical balance, until $100 \mathrm{~g}$ of powder was obtained. E. longifolia Jack root powder was wrapped in filter paper, and then, it was immersed with ethanol in the tubes until all powders in the filter paper were immersed in ethanol solvent for around 1 week. The result was evaporated using rotary evaporator and nitrogen gas to separate E. longifolia Jack roots from the ethanol solvent.

\section{PC-3 cell line culture}

The culture of prostate cancer PC-3 cell line was obtained from androgen-independent prostate adenocarcinoma with bone metastasis (PC-3 cell line ATCC $^{\mathrm{R}}$ CRL-1435 ${ }^{\mathrm{TM}}$ ). The basic medium used was the Eagle's Minimum Essential Medium (MEM). Complete growth medium was made by adding fetal bovine serum $10 \%$ and $2 \mathrm{mM} \mathrm{L-glutamine} \mathrm{into} \mathrm{the} \mathrm{basic} \mathrm{medium.}$

The prostate cancer PC-3 cells were washed with saline buffer, and the suspension was poured through $100 \mathrm{~mm}$ mesh. The cells were cultured in MEM prepared for fetal bovine serum growth. The culture was incubated in atmospheric humidity at $37^{\circ} \mathrm{C}$ with $95 \%$ air and $5 \% \mathrm{CO}_{2}$. The cells were left adherent for $<1$ week, while kept changing the medium every 2-3 days. Cell harvest was conducted after $80 \%$ cells were confluent. The cells were washed twice with phosphate buffer saline (PBS), and trypsin-ethylenediaminetetraacetic acid (EDTA) was added. The cells were incubated in the incubator for $3 \mathrm{~min}$. A $5 \mathrm{~mL}$ complete Roswell Park Memorial Institute (RPMI) was added to inactivate trypsin. Cell resuspension was conducted with pipette until each cell was separated. Separated cells were transferred into new sterile conical tubes.

\section{Assessment of apoptosis of prostate adenocarcinoma PC-3 cells using the TUNEL assay}

Cells were seeded at $6 \times 10$ cells/well in 24-well culture plate. The cells are exposed to E. Iongifolia
Jack extract with various doses $(100,50,25,12.5$, and $6.25 \mathrm{\mu g} / \mathrm{ml}$ ) and time ( $24 \mathrm{~h}$ and $48 \mathrm{~h}$ ) and stored again in $5 \% \mathrm{CO}_{2}$ incubators, $37^{\circ} \mathrm{C}$. After the incubation process is complete, the plate is removed from the incubator, the media are removed carefully, and the staining process of tunnel apoptosis is performed. Apoptotic cell was observed in prostate cancer cell samples with the terminal deoxynucleotidyl transferase-mediated dUTP biotin nick end labeling (TUNEL) method using in situ cell detection kit from the manufacturer. Cultured cells were washed three times with $\mathrm{PBS}$ at $\mathrm{pH} 7.4$, then cells were incubated with $20 \mu \mathrm{g} / \mathrm{mL}$ proteinase-K for 15 minutes at $37^{\circ} \mathrm{C}$. After that, the cells were washed 3 times with PBS at $\mathrm{pH} 7.4$ for 5 min each, and then, they were incubated with $3 \% \mathrm{H}_{2} \mathrm{O}_{2}$ for $15 \mathrm{~min}$. The cells were washed 3 times with PBS at $\mathrm{pH} 7.4$ for 5 min each; then, they were incubated with TUNEL fragmented DNA labeling for $60 \mathrm{~min}$ at $37^{\circ} \mathrm{C}$. The cells were washed 3 times with $\mathrm{PBS}$ at $\mathrm{pH} 7.4$ for 5 min each, and then, they were incubated with diaminobenzidine (DAB) substrate for $40 \mathrm{~min}$ at $37^{\circ} \mathrm{C}$. The cells were washed 3 times with PBS at pH 7.4 for 5 min each, and then, the cells were counterstained with Mayer's hematoxylin, incubated for $10 \mathrm{~min}$, and washed with tap water. The cells were rinsed with $\mathrm{dH} 20$ and air-dried. Mounting was conducted with Entellan and covered with the cover glass. Samples were examined with a light microscope. Apoptotic index was counted and stated as a percentage by dividing the TUNEL-positive cell count with the total prostate cancer cells (300-500). Positive immunostaining was evaluated randomly for three visual fields, and the average was counted with ImageJ program.

\section{Results}

The percentages of apoptotic adenocarcinoma cells after the administration of E. longifolia Jack root extract in various concentrations for $24 \mathrm{~h}$ are shown in Table 1.

Table 1: Percentage of apoptotic adenocarcinoma cells assessed with TUNEL assay, 24 hours after the administration of E. longifolia Jack root extract

\begin{tabular}{lllllll}
\hline Treatment & \multicolumn{7}{l}{ Apoptotic cells (\%) } & & & & \\
\cline { 2 - 7 } & 1 & 2 & 3 & 4 & 5 & Mean \pm SD \\
\hline Control & 12.63 & 14.55 & 12.19 & 15.86 & 15.35 & $14.1 \pm 1.63$ \\
$6.25 \mu \mathrm{g} / \mathrm{ml}$ & 18.36 & 20.20 & 16.67 & 14.6 & 11.76 & $16.3 \pm 3.28$ \\
$12.5 \mu \mathrm{g} / \mathrm{ml}$ & 14.19 & 17.42 & 27.73 & 16.18 & 26.07 & $20.3 \pm 6.15$ \\
$25 \mu \mathrm{gl} l$ & 23.12 & 17.01 & 27.85 & 18.90 & 28.27 & $23.0 \pm 5.10$ \\
$50 \mu \mathrm{g} / \mathrm{ml}$ & 23.30 & 24.63 & 23.39 & 19.31 & 29.97 & $24.1 \pm 3.83$ \\
$100 \mu \mathrm{g} / \mathrm{ml}$ & 54.18 & 47.99 & 33.64 & 20.90 & 40.15 & $39.4 \pm 12.93$ \\
\hline
\end{tabular}

The percentage of apoptotic adenocarcinoma cells was analyzed with ANOVA test after the data normality and homogeneity assumption tests were conducted. The normality assumption was tested with Kolmogorov-Smirnov test, while the homogeneity test was conducted with Levene test. Data normality and 
homogeneity assumptions are fulfilled when p-value is the same or higher than $\alpha(0.05)$. p-values for apoptosis variable are 0.098 and 0.135 , more than $\alpha(p>0.05)$. It means that the data normality and homogeneity assumptions have been fulfilled, and the hypothesis testing can be continued with one-way ANOVA.

The effect of $E$. longifolia Jack root extract administration at several concentrations on apoptosis in adenocarcinoma cells after $24 \mathrm{~h}$ was analyzed with ANOVA and then continued with Tukey HSD.

Based on the analysis results in Table 2, p-value is 0.000 , which is lower than 0.05 . It can be concluded that there was a significant difference between E. longifolia Jack root extract at various concentrations in the apoptosis of adenocarcinoma cells.

Table 2: The comparison of apoptotic adenocarcinoma cells using ANOVA and Tukey HSD tests 24 hours after the administration of $E$. longifolia Jack root extract

\begin{tabular}{lll}
\hline Treatment & Mean \pm SD & p-value \\
\hline Control & $14.1 \pm 1.63$ & 0.000 \\
$6.25 \mu \mathrm{g} / \mathrm{mL}$ & $16.3 \pm 3.28$ & \\
$12.5 \mu \mathrm{g} / \mathrm{mL}$ & $20.3 \pm 6.15$ & \\
$25 \mu \mathrm{gL}$ & $23.0 \pm 5.10$ & \\
$50 \mu \mathrm{g} / \mathrm{mL}$ & $24.1 \pm 3.83$ & \\
$100 \mu \mathrm{g} / \mathrm{mL}$ & $39.4 \pm 12.93$ & \\
\hline
\end{tabular}

Tukey HSD test results in Table 2 showed that the group given $E$. longifolia Jack root extract at the concentration of $100 \mu \mathrm{g} / \mathrm{mL}$ had the highest average of apoptosis, while the control group showed the lowest average of apoptosis.

The percentages of apoptotic adenocarcinoma cells after the administration of $E$. longifolia Jack root extract in various concentrations for $48 \mathrm{~h}$ are shown in Table 3. The effect of $E$. longifolia Jack root ethanol extract administration at several concentrations on apoptosis in adenocarcinoma cells after $48 \mathrm{~h}$ was analyzed with ANOVA and then continued with Tukey HSD.

Table 3: Percentage of apoptotic adenocarcinoma cells assessed with TUNEL assay, $48 \mathrm{~h}$ after the administration of E. longifolia Jack root extract

\begin{tabular}{lllllll}
\hline Treatment & \multicolumn{7}{c}{ Apoptotic cells (\%) } & & \\
\cline { 2 - 6 } & 1 & 2 & 3 & 4 & 5 & Mean \pm SD \\
\hline Control & 18.41 & 22.63 & 16.78 & 16.73 & 27.97 & $20.5 \pm 4.82$ \\
$6.25 \mu \mathrm{g} / \mathrm{ml}$ & 16.27 & 26.73 & 23.12 & 25.16 & 25.17 & $23.2 \pm 4.06$ \\
$12.5 \mu \mathrm{g} / \mathrm{ml}$ & 25.65 & 31.58 & 29.50 & 24.05 & 28.18 & $27.8 \pm 3.00$ \\
$25 \mu \mathrm{ml}$ & 36.7 & 44.45 & 17.72 & 26.05 & 28.13 & $30.6 \pm 10.27$ \\
$50 \mu \mathrm{g} / \mathrm{ml}$ & 31.87 & 33.15 & 40.08 & 24.62 & 28.36 & $31.6 \pm 5.78$ \\
$100 \mu \mathrm{g} / \mathrm{ml}$ & 46.72 & 41.52 & 45.74 & 52.87 & 30.76 & $43.5 \pm 8.21$ \\
\hline
\end{tabular}

p-values for apoptosis variable are 0.086 and 0.161 , more than $\alpha(p>0.05)$. It means that data normality and homogeneity assumptions have been fulfilled, and the hypothesis testing can be continued with one-way ANOVA.

Based on the analysis results in Table 4, $p$-value is 0.000 , which is lower than 0.05 . It can be concluded that there was a significant difference between $E$. longifolia Jack root extract at various concentrations in the apoptotic adenocarcinoma cells.

Tukey HSD test results in Table 4 showed that the group given $E$. longifolia Jack root extract at the concentration of $100 \mu \mathrm{g} / \mathrm{mL}$ had the highest average of apoptosis, while the control group showed the lowest average of apoptosis.

Table 4: The comparison of apoptotic adenocarcinoma cells using ANOVA and Tukey HSD tests after $48 \mathrm{~h}$ after the administration of $E$. longifolia Jack root extract

\begin{tabular}{lll}
\hline Treatment & Mean \pm SD & p-value \\
\hline Control & $20.5 \pm 4.82$ & 0.000 \\
$6.25 \mu \mathrm{g} / \mathrm{mL}$ & $23.2 \pm 4.06$ & \\
$12.5 \mu \mathrm{g} / \mathrm{mL}$ & $27.8 \pm 3.00$ & \\
$25 \mu \mathrm{gL}$ & $30.6 \pm 10.27$ & \\
$50 \mu \mathrm{g} / \mathrm{mL}$ & $31.6 \pm 5.78$ & \\
$100 \mu \mathrm{g} / \mathrm{mL}$ & $43.5 \pm 8.21$ & \\
\hline
\end{tabular}

Based on apoptotic adenocarcinoma cell data, the values of $\mathrm{IC}_{50}$ for $E$. longifolia Jack root extract treatment after 24 and $48 \mathrm{~h}$ were counted. The values of $\mathrm{IC}_{50}$ are shown in Figure 1.

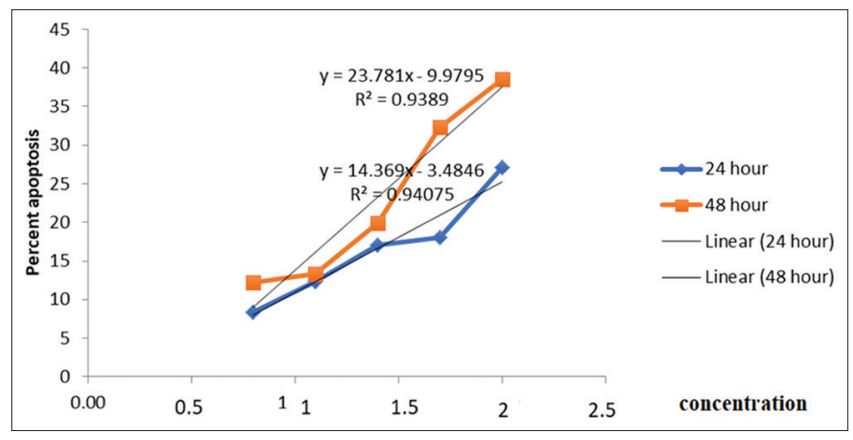

Figure 1: Values of $I C_{50}$ for E. longifolia Jack extract after 24 $(7.99 \mu \mathrm{g} / \mathrm{mL})$ and $48(7.71 \mu \mathrm{g} / \mathrm{mL}) \mathrm{h}$.

The results of the TUNEL assay as a marker of adenocarcinoma apoptotic cells after 24 and $48 \mathrm{~h}$ are shown in Figures 2 and 3.

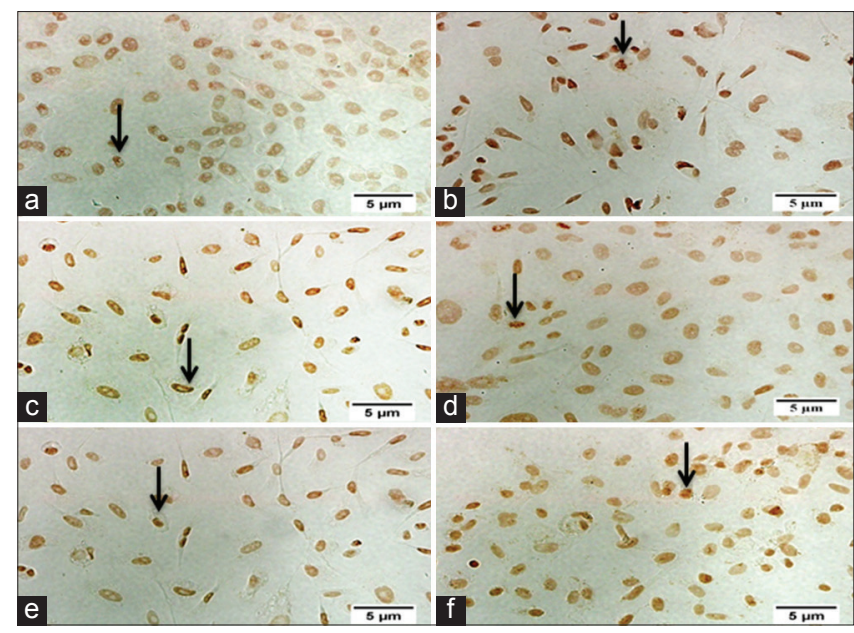

Figure 2: Apoptotic adenocarcinoma cells were characterized by brown color in the nucleus, shown by the TUNEL assay after $24 \mathrm{~h}$. (A) Control, (B) adenocarcinoma cells given E. longifolia Jack root extract at the concentration of $6.25 \mu \mathrm{g} / \mathrm{mL}$, (C) adenocarcinoma cells given E. longifolia Jack root extract at the concentration of $12.5 \mu \mathrm{g} / \mathrm{mL}$, (D) adenocarcinoma cells given E. longifolia Jack root extract at the concentration of $25 \mu \mathrm{g} / \mathrm{mL}$, (E) adenocarcinoma cells given E. longifolia Jack root extract at the concentration of $50 \mu \mathrm{g} / \mathrm{mL}$, (F) adenocarcinoma cells given E. longifolia Jack root extract at the concentration of $100 \mu \mathrm{g} /$ $\mathrm{mL}$. Apoptotic cell area was analyzed with ImageJ program.

Figures 2 and 3 show apoptosis in adenocarcinoma cells after the administration of E. longifolia Jack root extract. Apoptotic cells were 
characterized by dark brown nuclei, shown by arrows.

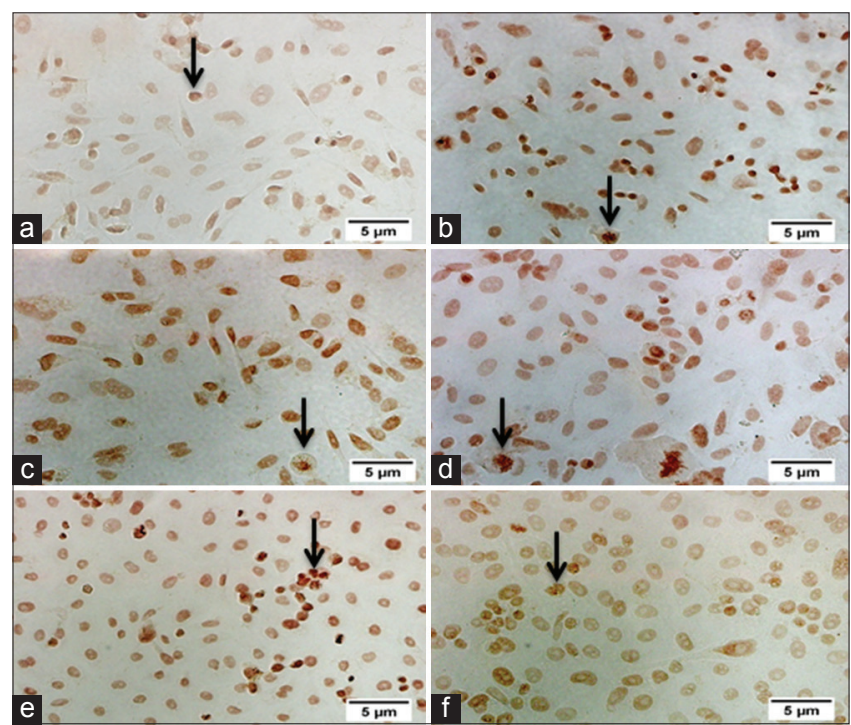

Figure 3: Apoptotic adenocarcinoma cells were characterized by brown color in the nucleus, shown by the TUNEL assay after $48 \mathrm{~h}$. (A) Control, (B) adenocarcinoma cells given E. longifolia Jack root extract at the concentration of $6.25 \mu \mathrm{g} / \mathrm{mL}$, (C) adenocarcinoma cells given E. longifolia Jack root extract at the concentration of $12.5 \mu \mathrm{g} / \mathrm{mL}$, (D) adenocarcinoma cells given E. longifolia Jack root extract at the concentration of $25 \mu \mathrm{g} / \mathrm{mL}$, (E) adenocarcinoma cells given E. Iongifolia Jack root extract at the concentration of $50 \mu \mathrm{g} / \mathrm{mL}$, (F) adenocarcinoma cells given E. longifolia Jack root extract at the concentration of $100 \mu \mathrm{g} /$ $\mathrm{mL}$. Apoptotic cell area was analyzed with ImageJ program.

Figure 4 shows the comparison of the average percentage of apoptosis in adenocarcinoma cells. The highest average apoptotic cell percentage was given by the treatment with $E$. longifolia Jack root extract at the concentration of $100 \mu \mathrm{g} / \mathrm{mL}$, with average percentages of $39.4 \%(24 \mathrm{~h})$ and $43.5 \%(48 \mathrm{~h})$. Based on the analysis, E. longifolia Jack root extract at the concentration of $100 \mu \mathrm{g} / \mathrm{ml}$ had the highest effect on the increase apoptotic cells.

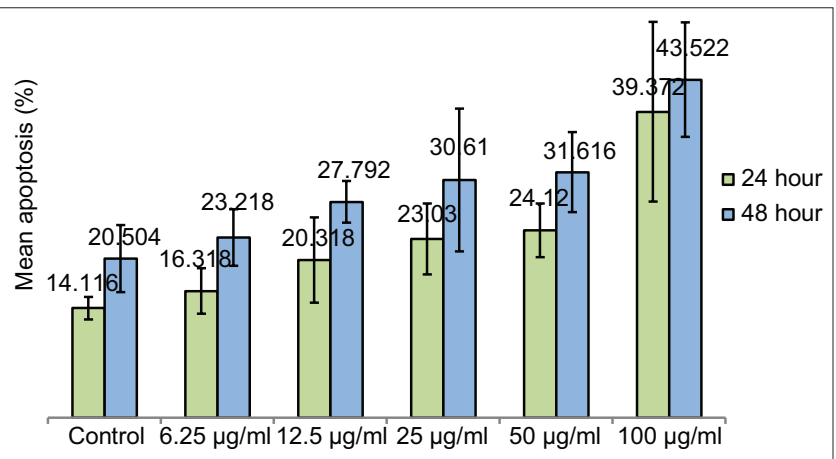

Figure 4: Comparison of the average percentage of apoptotic adenocarcinoma cells given E. longifolia Jack root extract at various concentrations after 24 and $48 \mathrm{~h}$.

\section{Discussion}

E. longifolia Jack (known as Pasak Bumi) is one kind of endemic plant in South Borneo, Indonesia.
It belongs to Simaroubaceae family and believes a function as an aphrodisiac [14]. The plant is reported to be rich in various classes of bioactive compounds such as quassinoids, canthin-6-one alkaloids, $\beta$-carboline alkaloids, triterpene tirucallane type, squalene derivatives and biphenyl neolignan, eurycolactone, laurycolactone, and eurycomalactone, and bioactive steroids. Among these phytoconstituents, quassinoids account for a major portion of $E$. longifolia root phytochemicals [15]. Furthermore, E. longifolia Jack root known to consist of an essential active compound, such as eurycomanone, quassinoids, and canthine, which have anticancer effect [16]. Hajjouli et al. concluded that $E$. longifolia constituents, eurycomanone and eurycomanol, are the regulators of signaling pathways involved in proliferation, cell death, and inflammation [17]. The antitumor activity is one of the most impressive medicinal properties of quassinoids and has been well researched $[18,19]$. Many quassinoids display antitumor activity in different potencies [20].

In silico study by Rahman et al showed that only eurycomanone and quassinoids had $\mathrm{Pa}>\mathrm{Pi}$ for antineoplastic agonist, and the value was between 0.8 and 1 for apoptosis [21]. The analysis will be resulting probability of active $(\mathrm{Pa})$ and the probability of inactive ( $\mathrm{Pi})$ score with a range from 0 to 1 . If $\mathrm{Pa}>\mathrm{Pi}$ mean, it is potential for a specific therapeutic candidate [22]. Canthine showed a lower value. Based on the prediction as anticancer, active compounds, eurycomanone and quassinoids, have potency as therapeutic agents due to their ability as apoptotic agents and proliferation inhibitors by inhibiting active site of RAS protein [21].

Apoptosis is arguably one of the most potent forms of defense against cancer [23]. In cancer therapy, one approach that suppresses the tumor growth is by activating the apoptotic machinery in the cell due to the effect of anticancer agents. Therefore, the induction of apoptosis has been recognized as a strategy for the identification of anticancer drugs [24]. Apoptotic agents that suppress the proliferation of malignant cells by inducing apoptosis may represent a useful mechanistic approach to both, cancer chemoprevention and chemotherapy [25]. The phase of apoptotic execution involves the activation of several series caspases. Upstream caspase of the intrinsic pathway is caspase-9 while the extrinsic pathway is caspase 8 . The intrinsic and extrinsic pathways will converge to activate caspase- 3 which plays a role in the apoptotic nuclear effector [26]. Direct activation of the execution caspase can be used in anticancer therapeutic strategies by increasing the concentration of procaspase-3 [27].

This study showed that $E$. longifolia Jack root extract increased the apoptotic level of PC3 cells. There was a proportional correlation, where the higher the dose of E. longifolia root extract, the higher the apoptotic level of adenocarcinoma cells. In addition, after $24 \mathrm{~h}$ of treatment with E. longifolia Jack extract, cells showed an increase in the percentage of DNA damaged cells of $39.4 \%$ at highest concentration 
$(100 \mu \mathrm{g} / \mathrm{ml})$ and $43.5 \%$, after $48 \mathrm{~h}$ of incubation. This confirms that $E$. longifolia Jack extract induces early signs of apoptosis after $24 \mathrm{~h}$, but cell death takes longer. This strongly correlates to the study performed by Nurkhasanah et al. after exposure of HeLa cells with eurycomanone, the percentage of apoptotic cells in the annexin +/PI- quadrant increased from 24 to $48 \mathrm{~h}$ of exposure, thus indicating that eurycomanone induced apoptosis in HeLa cells [28]. Furthermore, it was found that treatment with $E$. longifolia Jack extract induced DNA fragmentation by TUNEL assay in PC3 cells as well, in a time- and concentration-dependent manner.

\section{Conclusion}

There is a clear effect of $E$. longifolia root extract administration on the increase in apoptotic prostate adenocarcinoma cells. E. longifolia active ingredients are potentially used in the treatment of prostate cancer by inducing apoptotic mechanisms.

\section{References}

1. Rawla P. Epidemiology of prostate cancer. World J Oncol. 2019;10(2):63-89. PMid:31068988

2. Bray F, Ferlay J, Soerjomataram I, Siegel RL, Torre LA, Jemal A. Global cancer statistics 2018: GLOBOCAN estimates of incidence and mortality worldwide for 36 cancers in 185 countries. CA Cancer J Clin. 2018;68(6):394-424. https://doi. org/10.3322/caac. 21492

PMid:30207593

3. Umbas $R$, Hardjowijoto $S$, Mochtar CA, Safriady $F$, Djatisoesanto W, Soedarso MA, et al. Panduan penanganan kanker prostat. IAUI. 2011:1;1.

4. Rahman AS, Yap MM, Shakaff AY, Ahmad MN, Dahari Z, Ismail $Z$, et al. A microcontroller based taste sensing system for the verification of Eurycoma longifolia. Sens Actuators B. 2004;101(1-2):191-8. https://doi.org/10.1016/j.snb.2004.01.024

5. Ang $\mathrm{HH}$. Cytotoxic and antimalarial constituents from the roots of Eurycoma longifolia. Fundam Clin Pharmacol. 2002;15:265-8.

6. Sangat HM, Zuhud EA, dan Damayanti EK. Kamus Penyakit dan Tumbuhan Obat Indonesia. Jakarta: Yayasan Obor Indonesia; 2000.

7. Ang HH, Hitotsuyanagi H, Fukaya H, Takeya K. Quassinoids from Eurycoma longifolia. Phytochemistry. 2002;59(8):833-7. https://doi.org/10.1016/s0031-9422(01)00480-0

PMid:11937162

8. Beddir AG, Ngwendson K. Eurycomaoside: A new quassinoid from the roots of Eurycoma longifolia. Chem Pharm Bull. 2003;51(11):1301-3. https://doi.org/10.1248/cpb.51.1301 PMid: 14600377

9. Nurani LH, Pramono S, Mustofa M. The Cytotoxicity of Extract of Eurycoma longifolia Jack Root on T47D Cell Line, Proceeding. Yogyakarta: International Symposium, Cancer, Ahmad Dahlan
University; 2008.

10. Tan HT, Raharja K. Obat-obat Penting: Khasiat, Penggunaan, dan Efek-Efek Sampingnya, Indonesia: PT Alex Media Komputindo Kelompok Gramedia; 2002. p. 810. https://doi. org/10.24198/farmasetika.v2i5.16780

11. Nurhanan MY, Hawairiah A, Ilham MA, Shukri M. Cytotoxic effects of the root extracts of Eurycoma longifolaia jack. Phytother Res. 2005;19(11):994-6. https://doi.org/10.1002/ ptr.1759

PMid: 16317660

12. Choo CY, Chan $\mathrm{KL}$. The toxicity of some quassinoids from Eurycoma longifolia. Planta Med. 2002;68(7):662-4. https://doi. org/10.1055/s-2002-32907

PMid:12143009

13. Ueda JY, Tezuka Y, Banskota AH, Tran QL, Harimaya Y, Saiki I, et al. Antiproliferative activity of Vietnamese medicinal plants. Biol Pharm Bull. 2002;25(6):753-60. https://doi.org/10.1248/ bpb.25.753

PMid:12081142

14. Alves IA, Miranda HM, Soares LA, Randau KP. Simaroubaceae family: Botany, chemical composition and biological activities. Rev Bras Farmacogn. 2014;24(4):481-501. https://doi. org/10.1016/j.bjp.2014.07.021

15. Rehman SU, Choe K, Yoo HH. Review on a traditional herbal medicine, Eurycoma longifolia jack (Tongkat Ali): Its traditional uses, chemistry, evidence-based pharmacology and toxicology. Molecules. 2016;21(3):331. https://doi.org/10.3390/ molecules21030331

PMid:26978330

16. Kuo PC, Damu AG, Lee KH, Wu TS. Cytotoxic and antimalarial constituents from roots of Eurycoma longifolia. Bioorg Med Chem. 2004;12(3):537-44. https://doi.org/10.1016/j. bmc.2003.11.017

PMid:14738962

17. Hajjouli S, Chateauvieux S, Teiten MH, Orlikova $B$ Schumacher $M$, Dicato $M$, et al. Eurycomanone and eurycomanol from Eurycoma longifolia jack as regulators of signaling pathways involved in proliferation, cell death and inflammation. Molecules. 2014;19(9):14649-66. https://doi. org/10.3390/molecules190914649

PMid:25230121

18. Jiwajinda S, Santisopasri V, Murakami A, Sugiyama $H$, Gasquet $\mathrm{M}$, Riad $\mathrm{E}$, et al. In vitro anti-tumor promoting and anti-parasitic activities of the quassinoids from Eurycoma longifolia, a medicinal plant in Southeast Asia. J Ethnopharmacol. 2002;82(1):55-8. https://doi.org/10.1016/ s0378-8741(02)00160-5

PMid:12169407

19. Miyake K, Tezuka Y, Awale S, Li F, Kadota S. Canthin-6-one alkaloids and a tirucallanoid from, Eurycoma longifolia and their cytotoxic activity against a human HT-1080 fibrosarcoma cell line. Nat Prod Commun. 2010;5(1):17-22. https://doi. org/10.1177/1934578×1000500105

PMid:20184012

20. Guo Z, Vangapandu S, Sindelar RW, Walker LA, Sindelar RD. Biologically active quassinoids and their chemistry: Potential leads for drug design. Curr Med Chem. 2005;12(2):173-90. https://doi.org/10.2174/0929867053363351

PMid:15638734

21. Rahman EY, Utomo DH, Ali M, Purnomo BB, Kania N. Evaluating the potency of active compounds from Eurycoma longifolia jack roots extract as prostate cancer therapy. Drug Invent Today. 2018;10(12):2374-7.

22. Goel RK, Singh D, Lagunin A, Poroikov V. PASS-assisted exploration of new therapeutic potential of natural products. 
Med Chem Res. 2011;20(9):509-1514. https://doi.org/10.1007/ s00044-010-9398-y

23. Ghavami S, Hashemi M, Ande SR, Yeganeh B, Xiao W, Eshraghi $\mathrm{M}$, et al. Apoptosis and cancer: Mutations within caspase genes. J Med Genet. 2009;46(8):497-510. https://doi. org/10.1136/jmg.2009.066944

PMid:19505876

24. Powell CB, Fung P, Jackson J, Dall'Era J, Lewkowicz D, Cohen I, et al. Aqueous extract of herba Scutellaria barbatae, a chinese herb used for ovarian cancer induces apoptosis of ovarian cancer cell lines. Gynecol Oncol. 2009;91(2):332-40. https://doi.org/10.1016/j.ygyno.2003.07.004

PMid:14599863

25. Alshatwi AA, Shafi G, Hasan TN, Al-Hazzani A, Alsaif MA Apoptosis-mediated inhibition of human breast cancer cell proliferation by lemon citrus extract. Asian Pac J Cancer Prev.
2011;12(6):1555-9.

PMid:22126498

26. Zhang MC, Liu HP, Demchik LL, Zhai YF, Yang DJ. Light sensitizes IFN-gamma-mediated apoptosis of HT-29 human carcinoma cells through both death receptor and mitochondria pathways. Cell Res. 2004;14(2):117-24. https://doi.org/10.1038/ sj.cr.7290210

PMid:15115612

27. Putt KS, Chen GW, Pearson JM, Sandhorst JS, Hoagland MS, Kwon JT. Small molecule activation of procaspase-3 to caspase- 3 as a personalized anticancer strategy. Nat Chem Biol. 2006;2(10):543-50. https://doi.org/10.1038/nchembio814 PMid: 16936720

28. Nurkhasanah M, Azimahtol HL. Eurycomanone induces apoptosis through the up-regulation of p53 in human cervical carcinoma cells. J Cancer Mol. 2008;4(4):109-15. 